\title{
Pictorial Stories as Media of Prime Assistance Learning For Vocational High School Students
}

\author{
Sri Emy Yuli Suprihatin \\ Department of Hospitality and Fashion Education-Faculty of Engineering-Yogyakarta State University \\ sri_emy@uny.ac.id
}

\begin{abstract}
This research is aimed to: 1) find the data of SMK Muhammadiyah 1 Imogiri Special Regency of Yogyakarta's teachers' obstacles in preparing pictorial stories as media of prime assistance learning, 2) produce pictorial stories as media of Prime Assistance learning of $X$ grade students of SMK Muhammadiyah 1 Imogiri, Special Regency of Yogyakarta. Methods of this research were the Research and Development methods. The steps of development in this research confirmed Borg \& Gall's procedure, namely: (1) research and information collecting; (2) planning; (3) develop preliminary form of product, (4) preliminary field testing; (5) main product revision; (6) main field testing; (7) operational product revision; (8) operational field testing; (9) final product revision; (10) dissemination and implementation. Pictorial stories' qualification as produced media was tested by instructional media expert and learning materials expert. Limited test was also done to $2 \mathrm{X}$-grade students of SMK Muhammadiyah 1 Imogiri. Besides, the field test was done twice, those were: small group test (12 students) and big group test ( 32 students). The subject of this research is X-grade students of SMK Muhammadiyah 1 Imogiri, Special Region of Yogyakarta. Data of this research was analyzed using descriptive statistic. Research findings: 1) the obstacles of SMK Muhammadiyah 1 Imogiri's teachers in preparing pictorial stories as media of prime assistance learning process are: a) the difficulty in making actual pictures to express prime assistance's activities, b) the difficulty in taking their time to produce pictorial stories as media, c) the difficulty in visualizing the prime assistance materials in pictorial stories' plot, d) the difficulty in composing pictorial stories' scripts; 2) pictorial stories with five topics for prime assistance learning process are qualified with high qualification levels by the learning materials expert (mean 3.41), media expert (mean 3.62). The quality of the media is also proved good through the limited test with high qualification level (mean 3.8), the small group test with high qualification level (mean 3.61), and the big group test with high qualification level (mean 3.76).
\end{abstract}

Keywords: development, pictorial stories as media, prime assistance

\section{INTRODUCTION}

Providing assistance for external customers is one of the theoretical subjects in the Educational Training Subject of Prime Assistance in Vocational High School. This competence is basic for the achievement of competence in other educational training subjects such as Entrepreneurship and Management of Fashion Business. Without mastering the providing assistancefor-external customers-competence, it is impossible for a graduate to work in fashion business field. The model of theoretical learning in Vocational High School is dominated by a lecture which serves concepts to be memorized. The small number of media used in the learning process makes students hardly absorb abstract concepts to be manifested in the ability to provide assistance for external customers. Teachers should have given examples of real cases in the field by demonstrating the real examples or concrete acts in class. The roles can be played by students so that students can understand the prime assistance subject better. However, not all teachers can demonstrate it because each teacher has different characteristics.

The problem can be solved by developing pictorial stories as media which is implemented in the problem-based learning process or simulation method-base learning process. The characteristic of problem-based learning process encourages students to think critically. This characteristic is highly recommended in the implementation of 2013 curriculum. Daniel Dike (2008:4) states that the ability to think critically in this global world is very important. By having the ability, a person is not only acted as the user or consumer of the existed knowledge but also as the inventor of the knowledge; a new thinker. Stories provided in the pictorial stories as learning media will help students to critically learn about the problem and how to solve it. The pictorial stories also offer meaningful learning about how to provide assistance by simulating the provided stories in the media.

In the learning process, the role of learning media is crucial. Learning media can help explain the learning materials. The media can actualize concepts. Good selection of learning media will improve students' creativity in teaching and learning process. It is supported by several reasons why learning media improve learning outcomes. According to Nana Sudjana and Ahmad Rivai (2005), "First, advantages of using learning media in the learning process are; a). the learning process will be more interesting for students, b). learning materials will have better meaning, c). teaching methods will be varied, and d). students will do more learning activities. Second, students' level of thinking as the human level of thinking, develops in steps; begins with concrete thought to abstract thought or begins with simple thought to complex thought."

In addition, Briggs in Sudirman Siahaan (2006), states that learning media is a way to deliver learning materials. Books, movies, video recordings, and slide programs are the examples. Schramm in Sudirman Siahaan (2006), explained that: 
Information contained and delivered in technology devices can be used for learning, as a consequence, learning media is the extent of teachers' roles. Pictorial stories as graphic media used in learning have practical meaning that clearly and strongly presents facts and ideas through the combination of words and pictures (Nana Sudjana and Ahmad Rivai, 2002:27). Other statements are stated by Sutherland and Arbuthnot (in Owen\&Nowel, 2001: 33) that pictorial stories have a real telling plot and the illustration in pictorial stories is as important as its texts. According to Sheu Hsiu-Chih (2008: 51), pictures in stories have to functions, namely: 1) giving thorough/complete understanding (comprehension), and 2) giving a stimulus to the imagination.

Based on the problems, this research is aimed to; a) find the data of SMK Muhamadiyah 1 Imogiri Special Regency of Yogyakarta's teachers' obstacles in preparing pictorial stories as media of prime assistance learning, b) produce pictorial stories as media of Prime Assistance learning of $\mathrm{X}$ grade students of SMK Muhamadiyah 1 Imogiri, Special Regency of Yogyakarta.

\section{RESEARCH METHODS}

\section{A. Procedure of Development}

Referring to Borg \& Gall's steps of development, this research of pictorial stories as media of assistance is conducted in following steps:

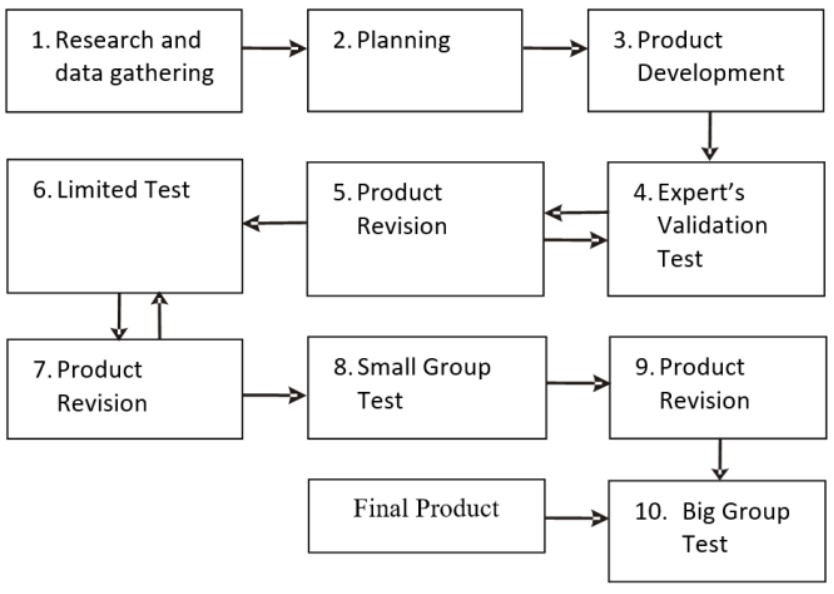

Fig. 1. Research Procedure

Notes:

1. Research and data gathering (research and information) In this process, several activities were done. They are examining competence standard (Standar Kompetensi / SK), basic competence (Kompetensi Dasar/KD) and indicators of assistance for external customers, analyzing compulsory material for pictorial stories as media based on competence standard (SK), basic competence (KD), and indicators.

2. Planning

The process of determining the objective formula in this research, constructing steps of research, preparing subject's materials, designing the type of pictorial stories, arranging validation instruments.

3. Product Development (develop preliminary form of product)

The process of producing learning media based on selected learning materials, the making of stories' plots, and the making of sketches, the process of illustrating, and the process of printing.

4. Expert's Validation Test (preliminary field testing) Learning media's validation involved learning materials' expert, learning media's expert, and a teacher of Prime Assistance subject of SMK Muhammadiyah 1 Imogiri.

5. Product Revision (main revision product)

In this step, several activities were done. They were fixing or refining products in accordance with advice taken when the process of expert's validation test.

6. Limited test (main field testing)

This step involved a teacher of Prime Assistance subject and two students of $\mathrm{X}$ grade of SMK Muhammadiyah 1 Imogiri.

7. Product Revision (operational product revision)

Fixing or refining the learning media in accordance with the limited test's result and advice was given by teachers and students.

8. Small Group Test (operational field testing) This process involved $12 \mathrm{X}$-grade students of SMK Muhammadiyah 1 Imogiri.

9. Product Revision

Fixing or refining learning media in accordance with the small group test's result and advice was given by teachers.

10. Big Group Test

This process involved $32 \mathrm{X}$-grade students of SMK Muhammadiyah 1 Imogiri. After this test, products were refined to be final products.Maintaining the Integrity of the Specifications

\section{B. Technique of Data Gathering and Research Instruments}

Data gathering of this research was done through questionnaires to get the data of; a) teachers' obstacles in making the learning media of prime assistance (instrument can be seen in Table I); b) qualification of materials' contents (instrument can be seen in Table II); c) qualification of media's appearance (instrument can be seen in Table III); d) qualification of pictorial stories as media from students' perception (instrument can be seen in Table IV).

TABLE I. INSTRUMENT IDENTIFICATION OF TEACHER'S OBSTACLES IN MAKING PICTORIAL STORIES AS MEDIA

\begin{tabular}{|c|l|c|c|}
\hline \multirow{2}{*}{ No } & \multicolumn{1}{|c|}{ Aspect } & \multicolumn{2}{c|}{ Score } \\
\cline { 3 - 4 } & & $\mathbf{0}$ & $\mathbf{1}$ \\
\hline 1. & $\begin{array}{l}\text { Good selection of media to express assistance for } \\
\text { external customers }\end{array}$ & & \\
\hline 2. & $\begin{array}{l}\text { Limitation of time to produce pictorial stories as } \\
\text { media }\end{array}$ & & \\
\hline 3. & $\begin{array}{l}\text { The input of assistance materials for external } \\
\text { customers through pictorial stories as media }\end{array}$ & & \\
\hline 4. & Scripts arrangement of pictorial stories & & \\
\hline 5. & The input of two-dimensional illustration pictures & & \\
\hline
\end{tabular}


TABLE II. INSTRUMENT OF THE CORRELATION OF MATERIAL'S CONTENTS IN PICTORIAL STORIES

\begin{tabular}{|c|l|c|c|c|c|}
\hline \multirow{2}{*}{ No } & \multicolumn{1}{|c|}{ Aspect } & \multicolumn{3}{|c|}{ Score } \\
\hline & & 1 & 2 & $\mathbf{3}$ & $\mathbf{4}$ \\
\hline 1. & $\begin{array}{l}\text { The correlation between the material and the } \\
\text { basic competence of providing assistance for } \\
\text { external customers }\end{array}$ & & & & \\
\hline 2. & $\begin{array}{l}\text { The correlation between the material and the } \\
\text { Indicators of providing assistance for external } \\
\text { customers }\end{array}$ & & & & \\
\hline 3. & $\begin{array}{l}\text { The material is properly organized in } \\
\text { accordance with the learning objective to } \\
\text { provide assistance for external customers }\end{array}$ & & & & \\
\hline 4. & $\begin{array}{l}\text { Plots in the pictorial stories reflect aspects of } \\
\text { providing assistance for external customers }\end{array}$ & & & & \\
\hline 5. & $\begin{array}{l}\text { Materials in pictorial stories are written in } \\
\text { proper language }\end{array}$ & & & & \\
\hline 6. & $\begin{array}{l}\text { Good selection of pictures is correlated with } \\
\text { the material of providing assistance for } \\
\text { external customers }\end{array}$ & & & & \\
\hline 7. & $\begin{array}{l}\text { The delivery of materials for external } \\
\text { customers in pictorial stories is harmonious }\end{array}$ & & & & \\
\hline 8. & $\begin{array}{l}\text { The delivery of material is correlated with } \\
\text { students' level of understanding }\end{array}$ & & & & \\
\hline 9. & $\begin{array}{l}\text { Pictures in pictorial stories clarify the material } \\
\text { of providing assistance for external customers }\end{array}$ & & & & \\
\hline 10. & $\begin{array}{l}\text { Good selection of pictures helps explain the } \\
\text { materials of providing assistance for external } \\
\text { customers }\end{array}$ & & & & \\
\hline 11. & $\begin{array}{l}\text { The use of pictorial stories as media eases } \\
\text { teachers in delivering the learning materials of } \\
\text { providing assistance for external customers }\end{array}$ & & & & \\
\hline 12. & $\begin{array}{l}\text { The use of pictorial stories encourages students } \\
\text { to learn more }\end{array}$ & & & & \\
\hline 13. & $\begin{array}{l}\text { The use of pictorial stories helps students focus } \\
\text { on the materials }\end{array}$ & & & & \\
\hline & & & & & \\
\hline
\end{tabular}

TABLE III. INSTRUMENT OF QUALIFICATION OF PICTORIAL STORIES LAYOUT

\begin{tabular}{|c|l|c|c|c|c|}
\hline \multirow{2}{*}{ No } & \multicolumn{1}{|c|}{ Aspect } & \multicolumn{3}{|c|}{ Score } \\
\hline & & $\mathbf{1}$ & $\mathbf{2}$ & $\mathbf{3}$ & $\mathbf{4}$ \\
\hline 1. & $\begin{array}{l}\text { Plot of the stories portrays concept of } \\
\text { providing assistance for external customers }\end{array}$ & & & & \\
\hline 2. & Facial expression portrays certain situation & & & & \\
\hline 3. & Gesture portrays certain situation & & & & \\
\hline 4. & The text is easily understood & & & & \\
\hline 5. & The text supports stories' plots in pictures & & & & \\
\hline 6. & $\begin{array}{l}\text { Texts in speech balloons are briefly, clearly, } \\
\text { and nicely arranged }\end{array}$ & & & \\
\hline 7. & The size of texts and pictures are proportional & & & & \\
\hline 8. & Good quality of the pictures' print-out & & & & \\
\hline 9. & \multicolumn{2}{|l}{ Media's convenience } & & & \\
\hline
\end{tabular}

TABLE IV. INSTRUMENT OF STUDENTS 'PERCEPTION OF PICTORIAL STORIES' QUALIFICATION

\begin{tabular}{|c|l|c|c|c|c|}
\hline \multirow{2}{*}{ No } & \multicolumn{1}{|c|}{ Component } & \multicolumn{3}{|c|}{ Score } \\
\cline { 3 - 6 } & \multicolumn{1}{|c|}{$\begin{array}{l}\text { 1 } \\
\text { Students' understanding of material in learning } \\
\text { process }\end{array}$} & & & & $\mathbf{3}$ \\
\hline 2. & $\begin{array}{l}\text { Learning process becomes easier and more } \\
\text { effective }\end{array}$ & & & \\
\hline 3. & $\begin{array}{l}\text { The daily advantage of material in providing } \\
\text { assistance for external customers }\end{array}$ & & & \\
\hline 4. & $\begin{array}{l}\text { Pictorial stories as media ease and make the } \\
\text { learning process more fun }\end{array}$ & & & \\
\hline 5. & $\begin{array}{l}\text { Pictorial stories as media make learning } \\
\text { process more interesting }\end{array}$ & & & \\
\hline 6. & Students are able to focus more on the learning & & & & \\
\hline
\end{tabular}

\begin{tabular}{|c|l|c|c|c|c|}
\hline \multirow{2}{*}{ No } & \multicolumn{1}{|c|}{ Component } & \multicolumn{4}{|c|}{ Score } \\
\hline & & $\mathbf{1}$ & $\mathbf{2}$ & $\mathbf{3}$ & $\mathbf{4}$ \\
\hline & process & & & & \\
\hline 7. & $\begin{array}{l}\text { Plot of the stories portrays concept of } \\
\text { providing assistance for external customers }\end{array}$ & & & & \\
\hline 8. & Facial expression portrays certain situation & & & & \\
\hline 9. & Gesture portrays certain situation & & & & \\
\hline 10. & The text is easily understood & & & & \\
\hline 11. & The text supports stories' plot in pictures & & & & \\
\hline 12. & $\begin{array}{l}\text { Texts in speech balloons are briefly, clearly, } \\
\text { and nicely arranged }\end{array}$ & & & \\
\hline 13. & The size of texts and pictures are proportional & & & & \\
\hline 14. & Good quality of the pictures' print-out & & & & \\
\hline 15. & Media's convenience & & & & \\
\hline
\end{tabular}

\section{Data Analysis Technique}

The used technique for the data analysis was the statistic descriptive technique. The qualification category of pictorial stories as media used was the Likert's Scale. Steps of the data analysis were:

a. Converting value to score, in accordance with Likert scale as follows:

Less qualified (Kurang Layak/KL) scored 1 Quite Qualified (Cukup Layak/CL) scored 2 Qualified (Layak/L) scored 3 Highly Qualified (Sangat Layak/SL) scored 4

b. Calculating total score and average score for each component using:

Formula: $\bar{X}=\frac{\sum X}{N}$

Notes: $\bar{X}=$ Each component/aspect's average score

$\begin{aligned} \sum X & =\text { number of value } \\ \mathrm{N} & =\text { number of comp }\end{aligned}$

c. The last final average score is qualitatively conversed to the qualification level of the product with following ideal conversion's manual.

TABLE V. CRITERIA OF IDEAL ASSESMENT

\begin{tabular}{|c|c|c|}
\hline No. & Score Range & Category of Quality \\
\hline 1. & $\mathrm{X}>\mathrm{Xi}+1,80 \mathrm{Sbi}$ & Highly Qualified ( SL) \\
\hline 2. & $\mathrm{Xi}+0,60 \mathrm{Sbi}<\mathrm{X} \leq \mathrm{Xi}+1,80 \mathrm{Sbi}$ & Qualified (L) \\
\hline 3. & $\mathrm{Xi}-0,60 \mathrm{Sbi}<\mathrm{X} \leq \mathrm{Xi}+0,60 \mathrm{Sbi}$ & Quite Qualified (CL) \\
\hline 4. & $\mathrm{Xi}-1,80 \mathrm{Sbi}<\mathrm{X} \leq \mathrm{Xi}-0,60 \mathrm{Sbi}$ & Less Qualified (KL) \\
\hline
\end{tabular}

SOURCE: SUKARDJO, 2006:53

Notes:

$\mathrm{X}$ : Final average score

$\mathrm{X} i$ : Ideal average, can be found with formula;

$\mathrm{X} i$ : (1/2) (highest ideal score + lowest ideal score)

Sbi : Simpangan baku ideal, can be found with formula;

Sbi : (1/6) (highest ideal score - lowest ideal score)

Based on the mentioned data conversion formula, after the quantitative data was gathered, the researcher converted it into qualitative data through this conversion: 


$$
\begin{aligned}
\text { Max score } & =4 \\
\text { Min score } & =1 \\
\mathrm{Xi} & =1 / 2(4+1) \\
\text { Sbi } & =1 / 6(4-1) \\
& =0,5 \\
\text { Scale 4 } & =\mathrm{X}>2,5+(1,8 \times 0,5) \\
& =\mathrm{X}>2,5+0,9 \\
\text { Scale 3 } & =2,5+(0,6 \times 0,5)<\mathrm{X} \leq 3,4 \\
& =2,5+0,3<\mathrm{X} \leq 3,4 \\
\text { Scale 2 } & =2,8<\mathrm{X} \leq 3,4 \\
\text { Scale 1 } & =2,5-0,3<\mathrm{X} \leq 2,8 \\
& =2,2<\mathrm{X} \leq 2,8 \\
& =2,5-0,9<\mathrm{X} \leq 2,2 \\
& =1,6<\mathrm{X} \leq 2,2
\end{aligned}
$$

Based on the mentioned calculation, the conversion of scale 4's quantitative data to scale 4's qualification data can be simplified as follows:

\section{TABLE VI. GUIDELINES OF IDEAL ASSESMENT CRITERIA'S} CONVERSION

\begin{tabular}{|c|c|}
\hline Range & Criteria \\
\hline $\mathrm{X}>3,4$ & Highly Qualified \\
\hline $2,8<\mathrm{X} \leq 3,4$ & Qualified \\
\hline $2,2<\mathrm{X} \leq 2,8$ & Quite Qualified \\
\hline $1,6<\mathrm{X} \leq 2,2$ & Less Qualified \\
\hline
\end{tabular}

TABLE VII. DESCRIPTION OF ASSESMENT

\begin{tabular}{|c|l|}
\hline Category & \multicolumn{1}{c|}{ Assessment } \\
\hline $\begin{array}{c}\text { Highly } \\
\text { Qualified }\end{array}$ & $\begin{array}{l}\text { Learning media is highly qualified when students clearly } \\
\text { understand the content of the learning material, more } \\
\text { enthusiastic to learn, capable to clearly present examples } \\
\text { of providing assistance to external customers. }\end{array}$ \\
\hline Qualified & $\begin{array}{l}\text { Learning media is qualified when students clearly } \\
\text { understand the content of the learning material, } \\
\text { enthusiastic to learn, and capable to present examples of } \\
\text { providing assistance for external customers. }\end{array}$ \\
\hline Quite & $\begin{array}{l}\text { Learning material is quite qualified when students } \\
\text { understand the content of the learning material, } \\
\text { enthusiastic to learn, and capable to present examples of } \\
\text { providing assistance for external customers. }\end{array}$ \\
\hline Less & $\begin{array}{l}\text { Learning media is less qualified when students unclearly } \\
\text { understand the content of the learning material, less } \\
\text { enthusiastic to learn, and unable to present examples of } \\
\text { providing assistance for external customers. }\end{array}$ \\
\hline
\end{tabular}

\section{RESULTS AND DISCUSSION}

\section{A. The Identification of Teachers' Obstacles in Preparing Learning Media to External Customers}

The teachers' obstacles in preparing learning media of prime assistance were successful to identify in the followings: 1) the difficulty in choosing the appropriate media to express the assistance for external customers, 2) the limitation of time to make pictorial stories, 3) the difficulty in visualizing the assistance material for external customers in pictorial stories

\begin{tabular}{|c|c|c|c|}
\hline $\begin{array}{c}\text { Standard } \\
\text { Competence }\end{array}$ & $\begin{array}{c}\text { Basic } \\
\text { Competence }\end{array}$ & Indicator & Material \\
\hline \multirow{3}{*}{$\begin{array}{l}\text { Providing } \\
\text { the prime } \\
\text { assistance } \\
\text { to customer } \\
\text { care. }\end{array}$} & \multirow{3}{*}{$\begin{array}{l}\text { Providing the } \\
\text { assistance to } \\
\text { the internal } \\
\text { and external } \\
\text { customers. }\end{array}$} & \multirow{3}{*}{$\begin{array}{l}\text { Providing the } \\
\text { assistance to } \\
\text { the external } \\
\text { customers. }\end{array}$} & $\begin{array}{l}\text { 1) Prime assistance } \\
\text { based on attitude } \\
\text { concept. }\end{array}$ \\
\hline & & & $\begin{array}{l}\text { 2) Prime assistance } \\
\text { based on attention } \\
\text { concept. }\end{array}$ \\
\hline & & & $\begin{array}{l}\text { 3) Prime assistance } \\
\text { based on action } \\
\text { concept. }\end{array}$ \\
\hline
\end{tabular}
media, 4) the difficulty in composing scripts of pictorial stories.

\section{B. The Development of Assistance Pictorial Stories Media to External Customers}

The development of pictorial story media was conducted by the appropriate procedure from Borg \& Gall, namely:

a. Research and Data Collection

Based on the documentation review of the prime assistance course syllabus in vocational high school, the score achievement of prime assistance competence, and the interview with the teachers, it came to the agreement that the material which will be poured in the picture story is based on the standard competence, basic competence, and indicators drawn in Table VIII.

TABLE VIII. THE MATERIAL OF PRIME ASSISTANCE IN PICTORIAL STORY MEDIA

\section{b. Planning}

Planning in making teaching media included to prepare the course material, design the type of pictorial stories, and prepare the stories content. In this study, the type of pictorial stories was a comic which did not have any series.

c. Developing the Products

The steps of developing the products as followings:

1) Making the Script

In making the script, we must have critical thinking and think about the plot in each story because it has different beginning and ending story, and it will be a bridge which connects to the story. In this study, the plot provides the assistance to external customers as followings:

Story 1

Customer : Good afternoon.

Boutique owner : Good afternoon. Can I help you?

Customer : Yes, Madam. I wante to sew a wedding gown. I am wondering, how long it takes?

Boutique owner : For making the wedding gown, it takes around 6 weeks. When do you wear?

Customer $\quad$ : It is around 3 months, so can you make it?

Boutique owner : Okay, I will try. Have you had the design?

Customer : I have already had the cloth and design. (showing the cloth and design)

Boutique owner : Okay, what is your name? and is there 
Com Anis. My phone number is
$08187 .$.

Boutique owner : Okay, let me measure your size. (after taking note of customer's phone number, she stands on and measures the customer's size)

Customer : (standing on to be measured)

Boutique owner : Excuse me. (starting to measure). It is done. Please take a seat. I will contact you in two weeks to have a first fitting.

Customer : Okay, I have to go.

Boutique owner : Sure, thank you for visiting this place.

\section{2) Making the Sketch}

This step began with making the sketch of story scene based on the script used by pencil. In this part, the imagination of the atmosphere, depiction of scenes, and creation of the pictures draw the story which the readers can understand easily.

Sketching was made in accordance with the layout of the plot story and dialog in the box. The text in a box must be short because the half of story is expressed by the pictures. Therefore the pictures were able to express and visualize the atmosphere in a story. Additionally, the compiled dialogs in the script would be adjusted to the conversation dialog in order to obtain the natural impression in a conversation.

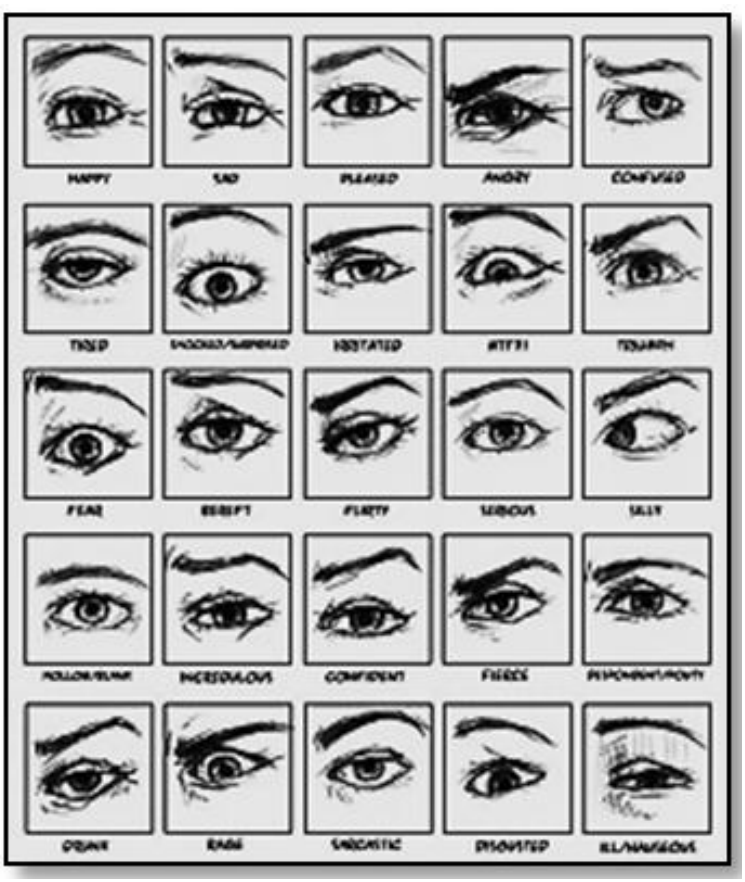

Fig. 2. Examples of Eyes Expression to Draw Mood

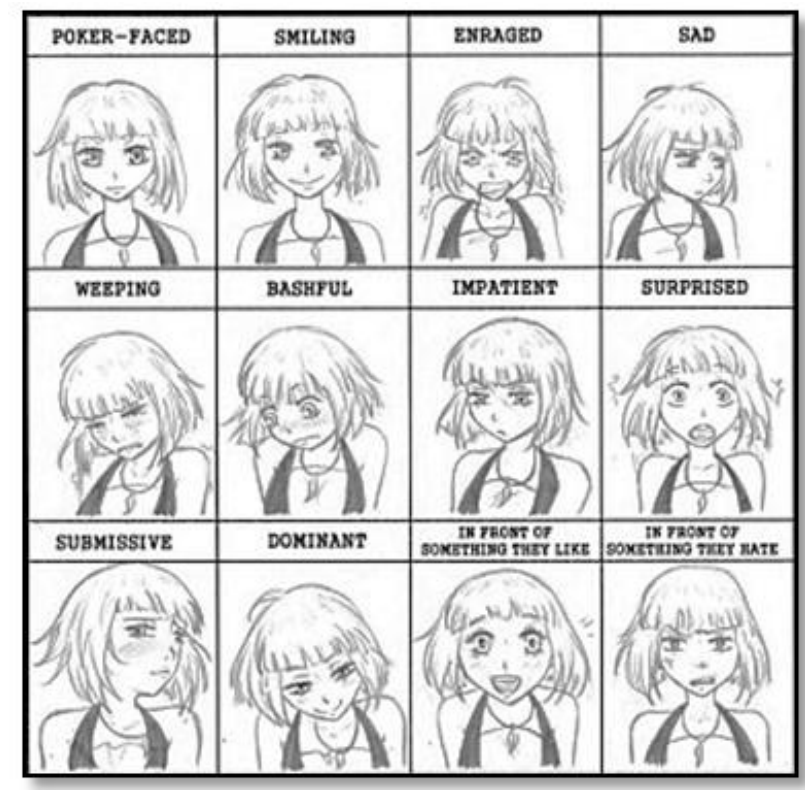

Fig. 3. Examples of Facial Expression

\section{3) Finishing}

In this step, the arrangements of plot story to be one frame were needed. Moreover, the reinforcement of sketch by drawing pen, marker, and Rotring was provided. In some parts, it should be blocked in black colors with Chinese ink using the mini brush. Then, the results of the pictures would be scanned by the computer and the results from the computer can be edited again using colors and texts in a dialog box.

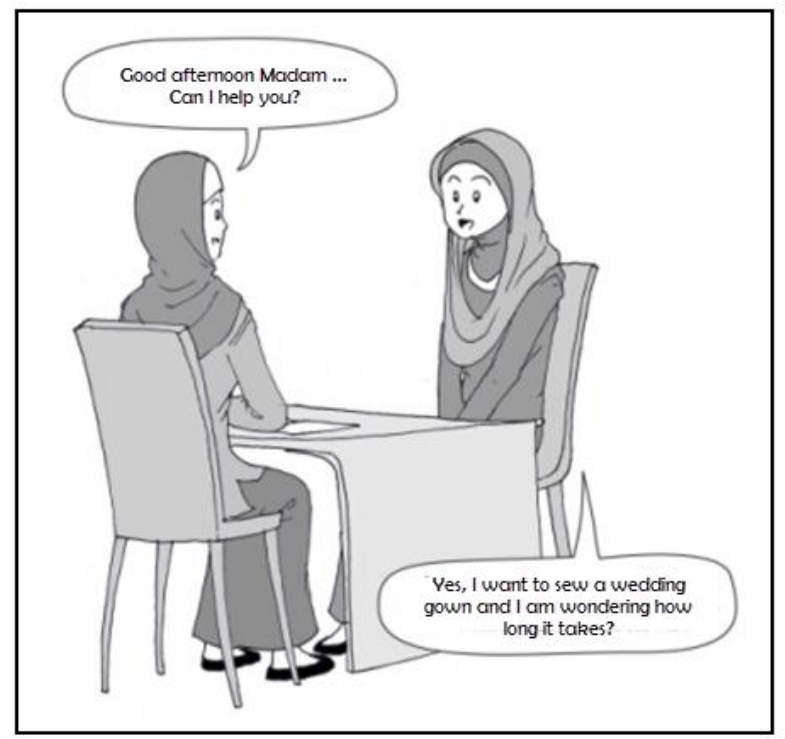

Dialog 1 


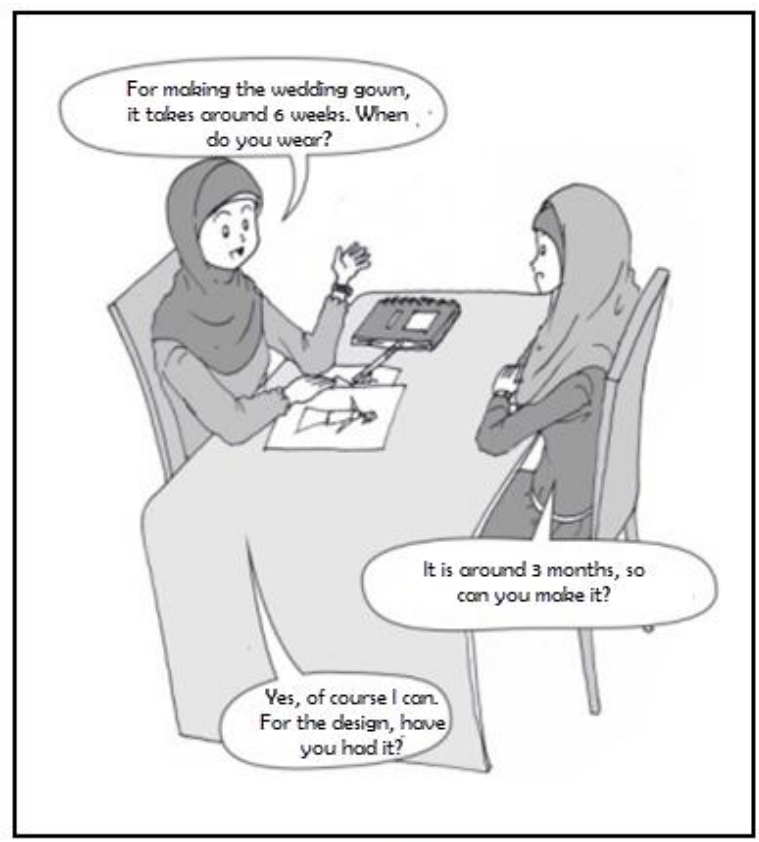

Dialog 2

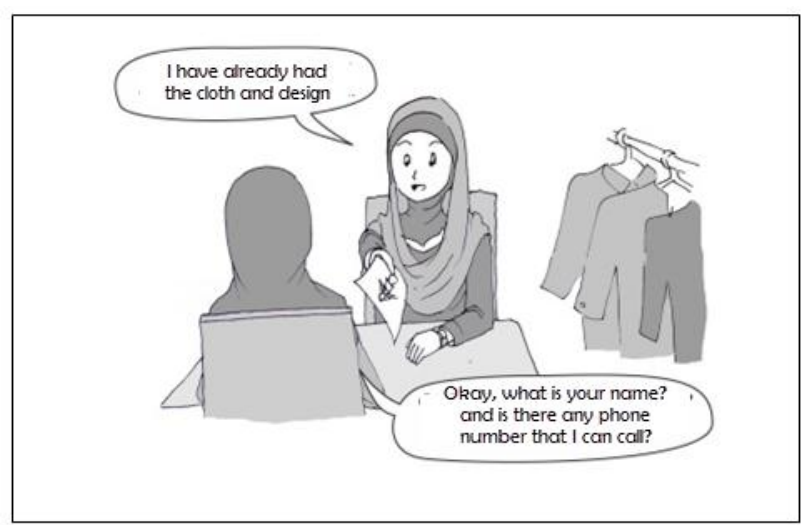

Dialog 3

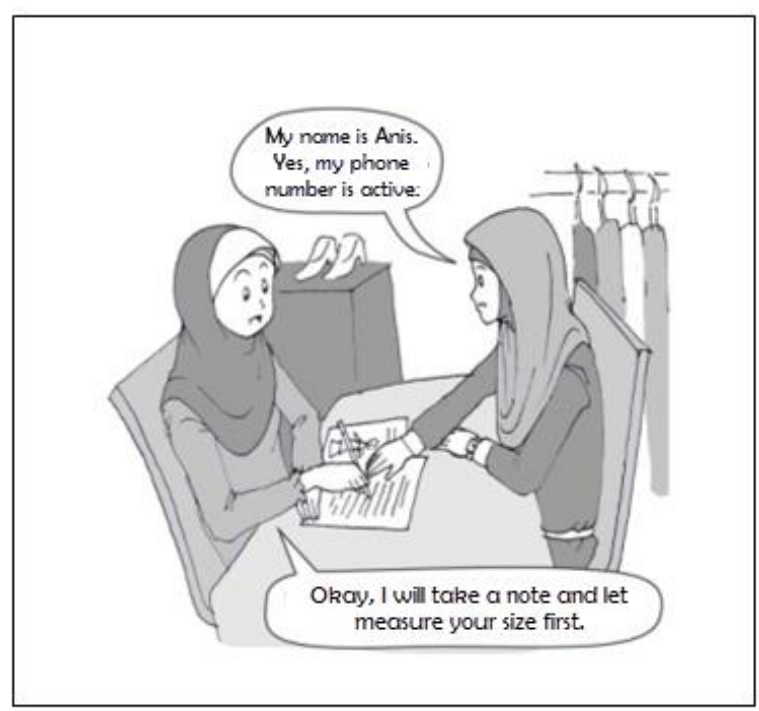

Dialog 4

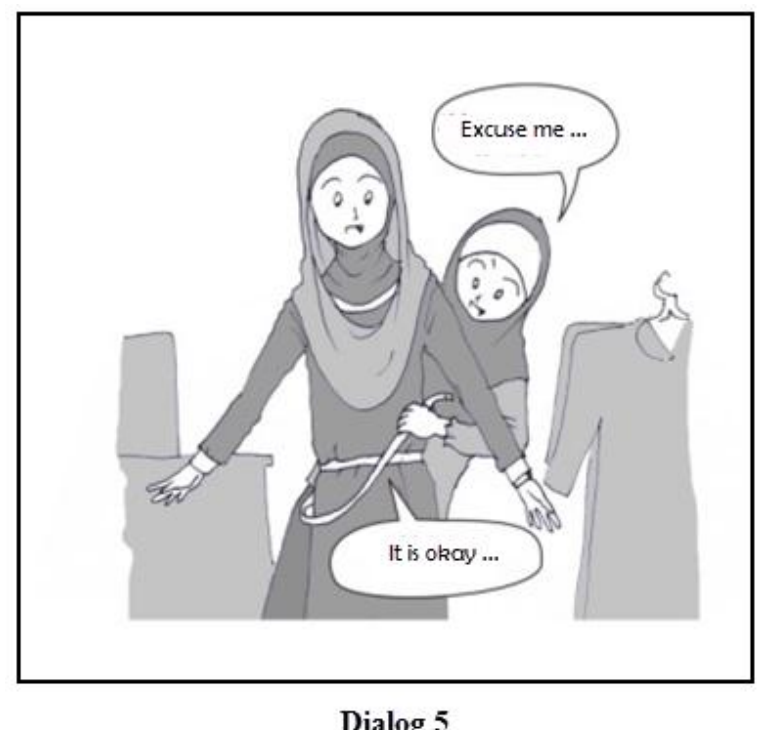

\section{d. Expert's Validation Test}

1) Material Expert Validation

Material validation was conducted to get the feedback of the material which is being developed. The results were used to revise the testing or experiment. Material experts in this study are the colleagues of consumer education course and two teachers of prime assistance course from SMK Muhammadiyah1Imogiri. The following validation results are given:

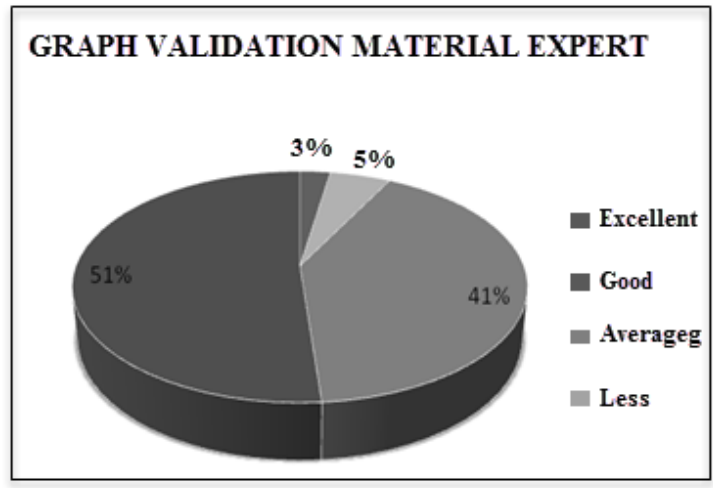

Fig. 4. Graph of Media Feasibility from Material Expert

\section{2) Medial Expert Validation}

Media validation was used to get the feedback from the feasibility media display. The results were to revise it before testing. Media experts in this study were the comic practitioner from ISI Yogyakarta and teachers of prime assistance course from SMK Muhammadiyah 1 Imogiri. The following validation results are given: 


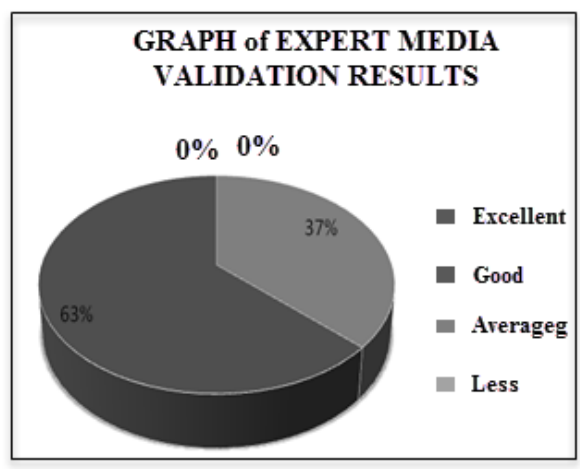

Fig. 5. Graph of Media Feasibility from Media Expert

\section{3) Limited Test}

Limited test was conducted after the media is validated by the material experts and media experts and received the feasibility recommendation to be tested. The limited test involved a teacher of prime assistance course and two students of class X from SMK Muhammadiyah 1 Imogiri. The following limited test results are:

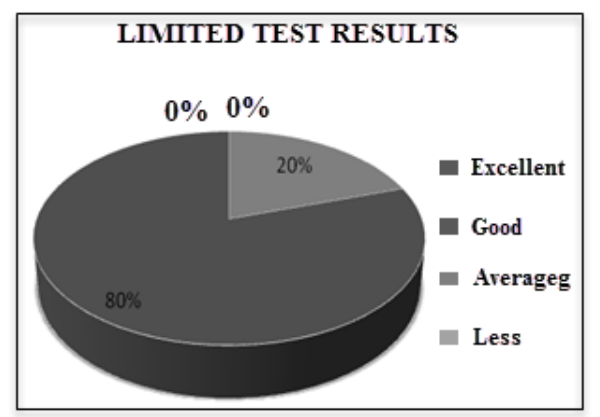

Fig. 6. Graph of Media Feasibility from Teachers' Opinion

\section{4) Small Group Test}

Small group test was conducted to get the responses of media quality both in terms of material content, technical, and impact on students' learning spirit. Small group test involved 12 students were taken randomly from 32 students (based on high, middle, and low rank). The following results of small group test are:

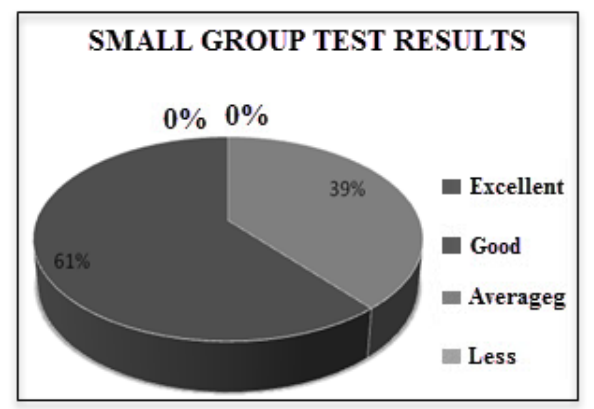

Fig. 7. Graph of Feasibility Media from Students (Opinion through Small Group Test)

\section{5) Big Group Test}

Big group test or field test was conducted after revising the data analysis from small group test. Field test involved 32 students in a classroom. The following results of the final step of the media product test process are:

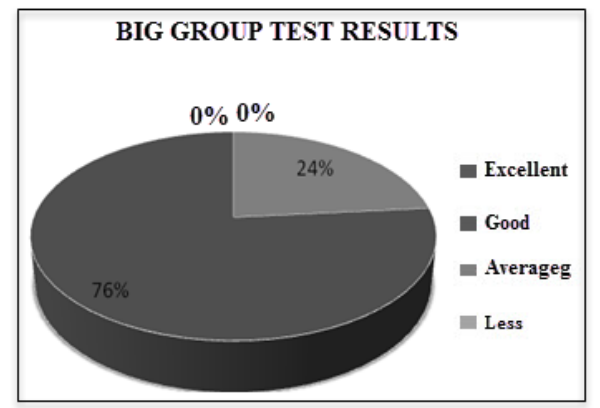

Fig. 8. Graph of Media Feasibility from Students (Opinion through Big Group Test)

Based on the development steps, there are 5 topics of pictorial stories in teaching media. The following scripts of prime assistance of pictorial stories are:

\section{Story 1}
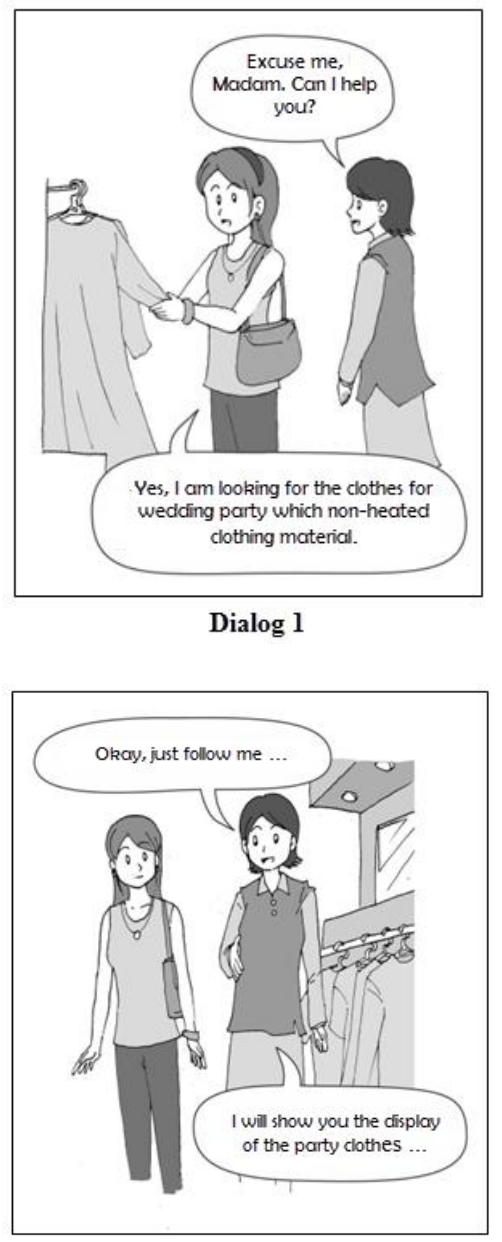

Dialog 2 


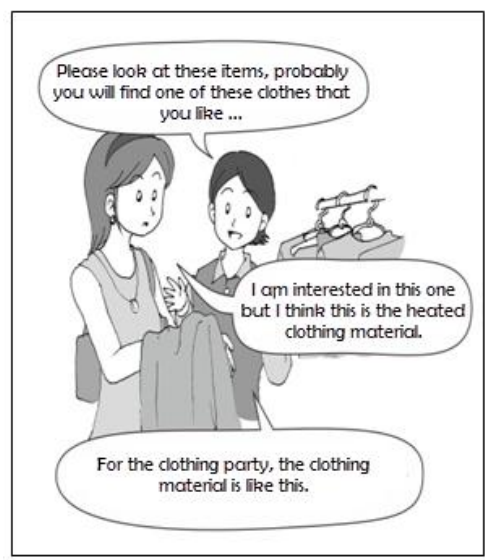

Dialog 3

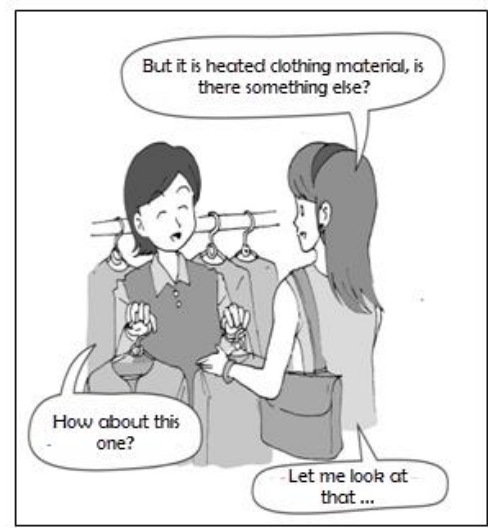

Dialog 4

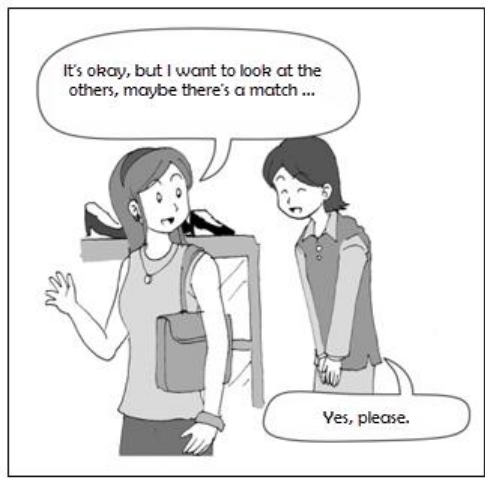

Dialog 5

\section{Story 2}

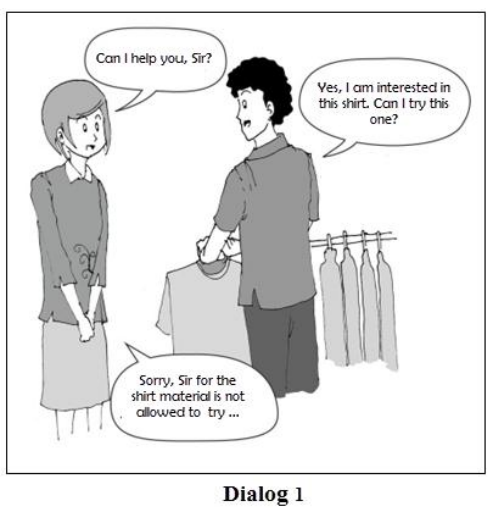

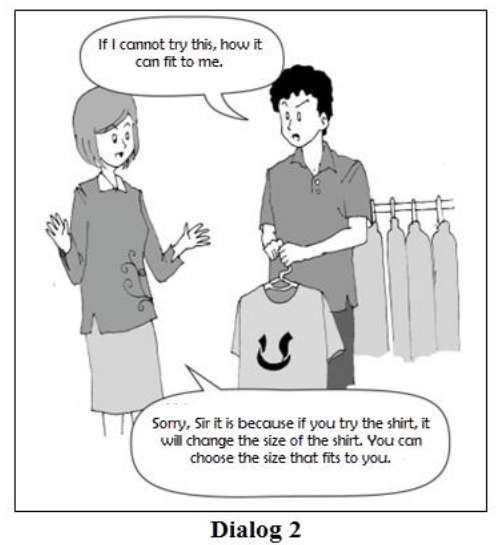

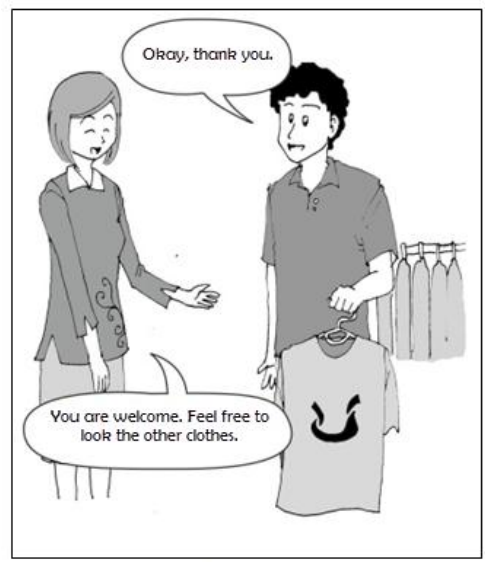

Dialog 3

\section{Story 3}
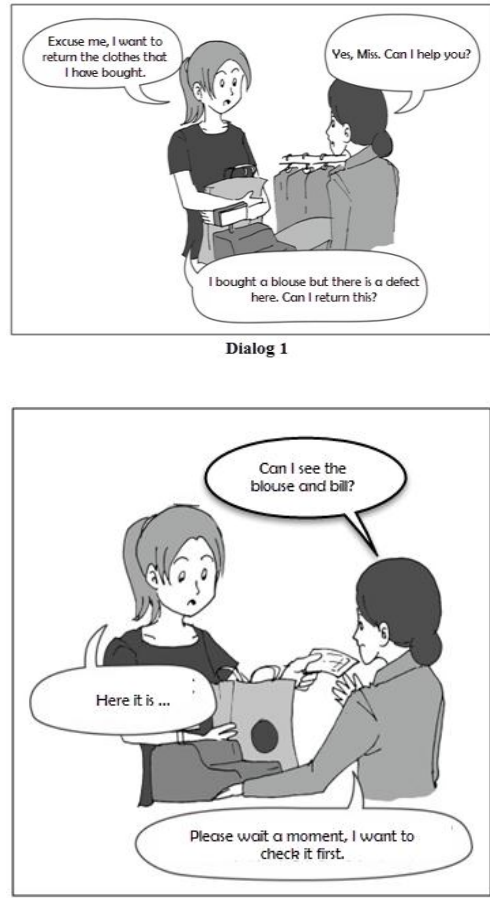

Dialog 2 

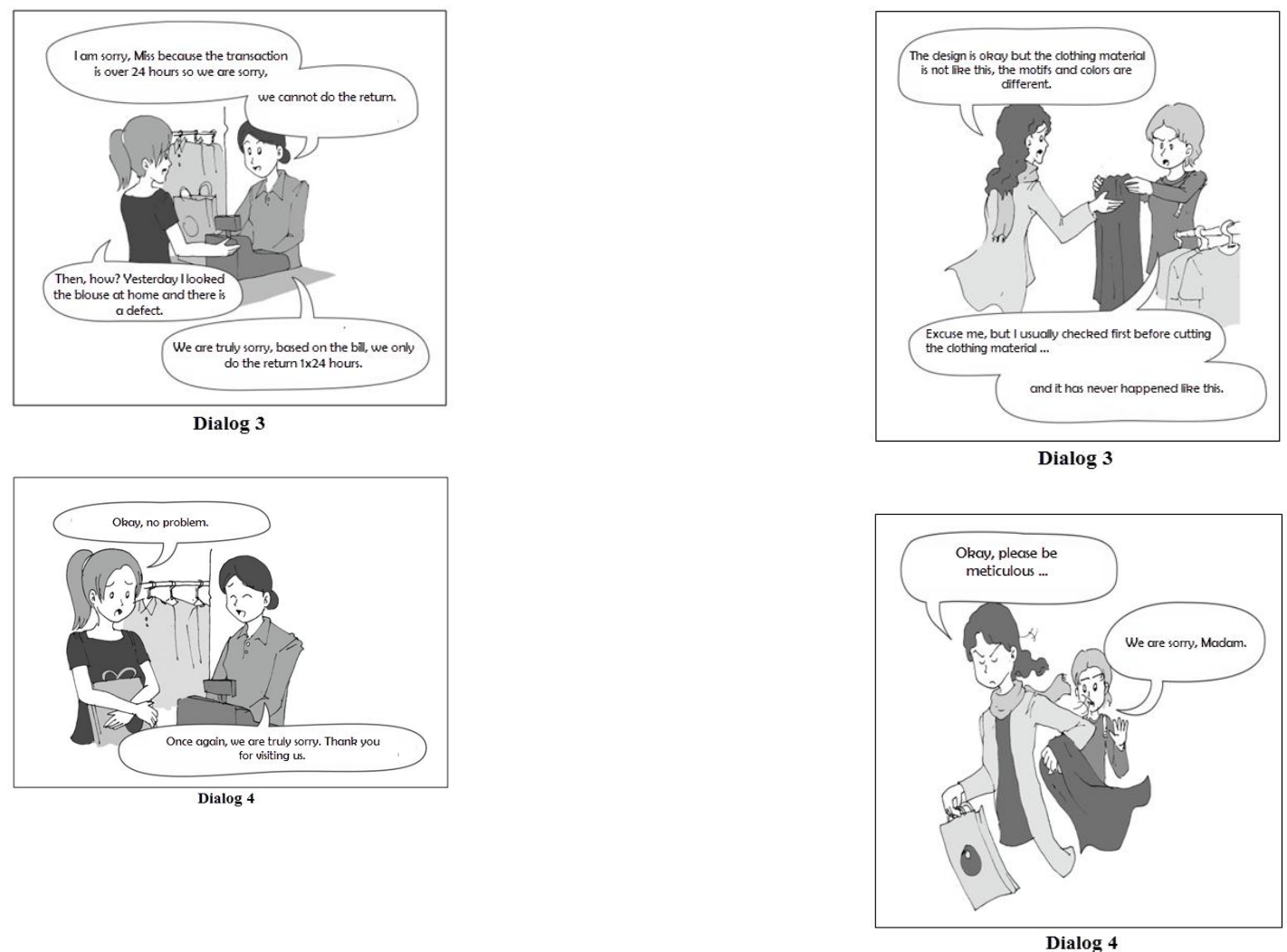

\section{Story 4}

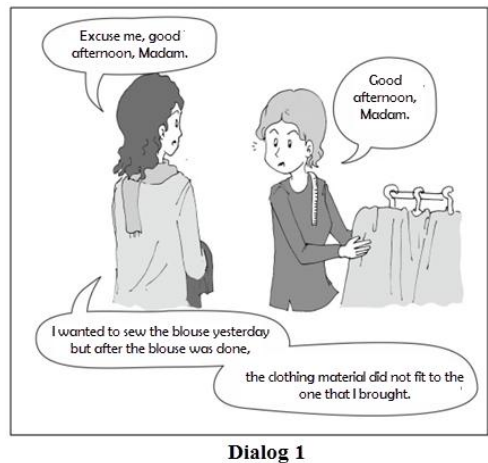

Story 5
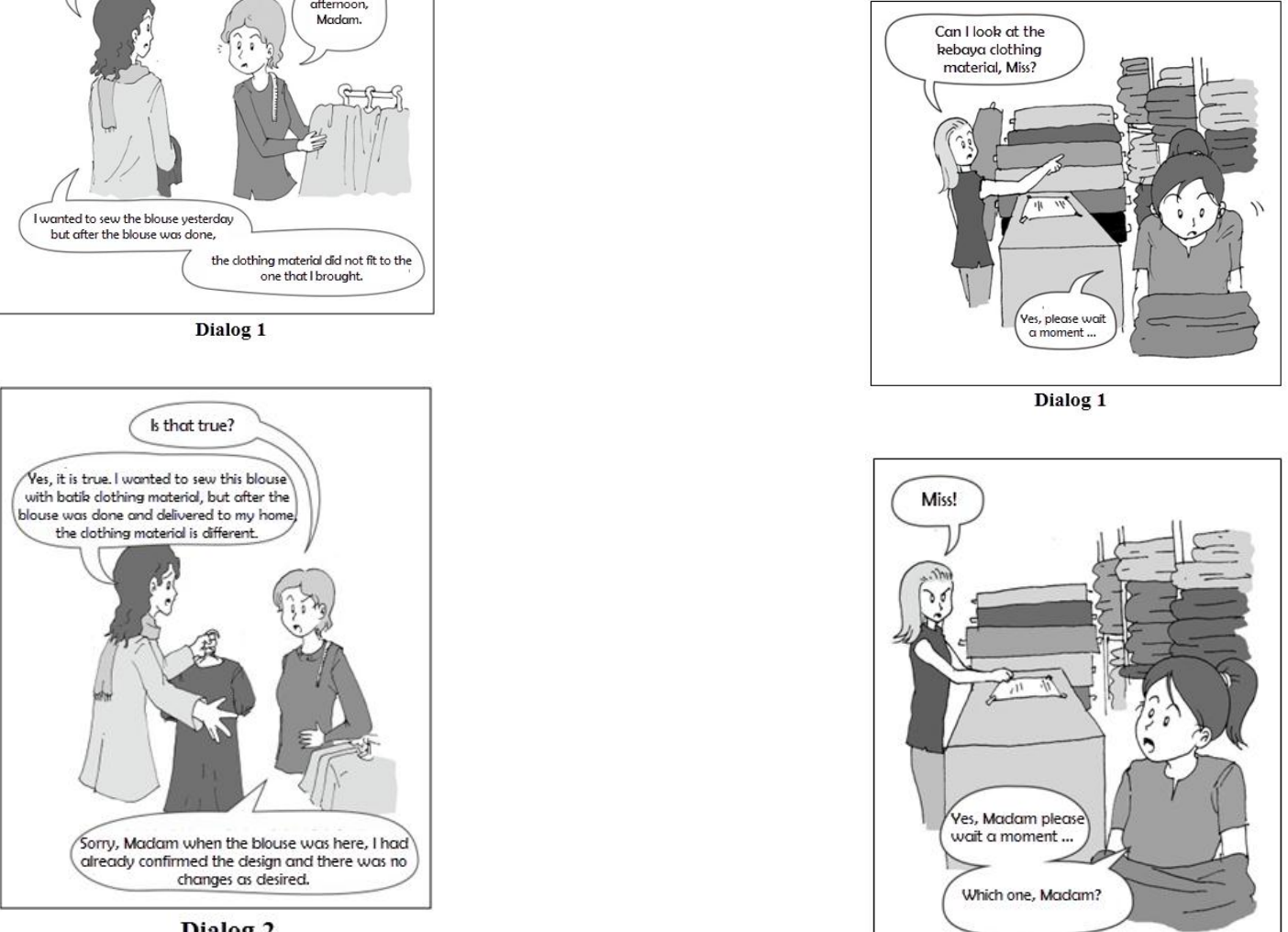

Dialog 1

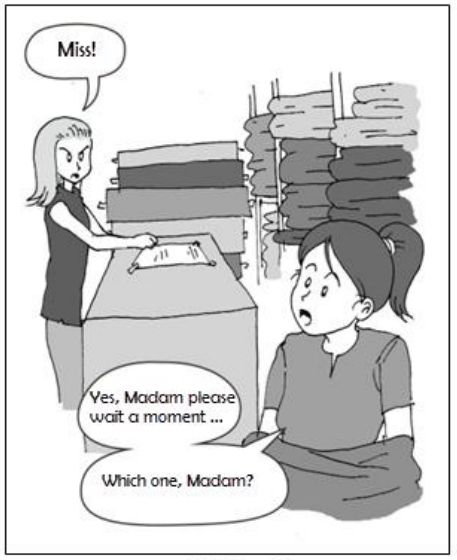

Dialog 2 

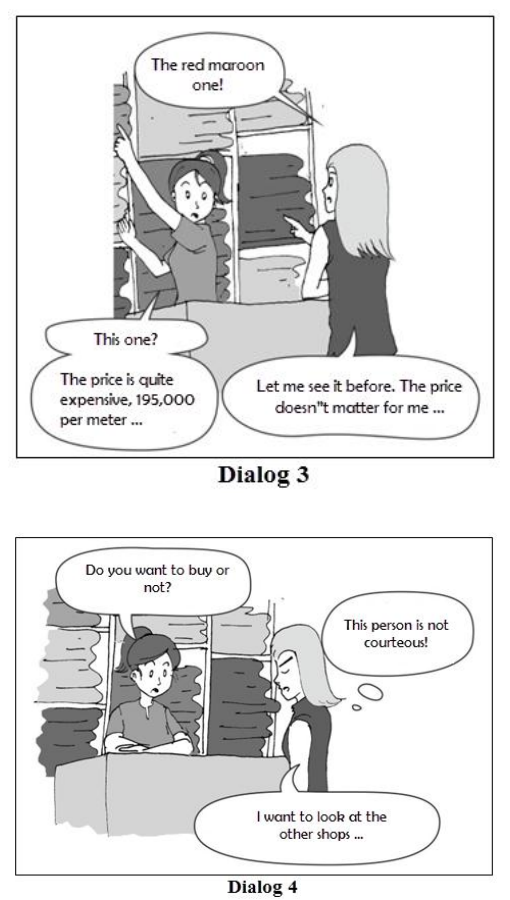

\section{CONCLUSION}

a. The teacher gets a new experience in preparing the teaching media and pouring the assistance material to the external customers into pictorial story media. The teacher is able to develop the material through the preparation of pictorial story media. The teacher also gets the experience in drawing two-dimensional illustrations.

b. A pictorial story media is being developed successfully through Borg \& Gall's development. The pictorial story is also produced 5 topics of a story. At the implementation stage in a classroom has shown a change in learning. The students not only accept the abstract concepts but also gain the drawing of assistances based on the plot provided in the story. It is in accordance with 2013 curriculum which forces the students to have critical thinking and solve the problem in prime assistance. Therefore in a working world, the students are able to implement it.

\section{REFERENCES}

[1] Dike, D. (2008). Peningkatan kemampuan berpikir kritis dalam model TASC (Thanking Actively in a Social Context pada pembelajaran IPS $S D$. Thesis. Yogyakarta: Magister Program State of Yogyakarta University.

[2] Owens, W. T. \& Nowel, L. S. (2001). More than just picture: Using picture storybooks to broaden young learners. Educational Journal. Retrieved on August.

[3] Sheu, H. C. (2008). The value of English picture story books. Oxford University Press

[4] Siahaan, S. (2006). Media pembelajaran PUSTEKKOM. National Education Department.

[5] Sudjana, N. \& Rivai, A. (2002). Media Pengajaran. Bandung: C.V Sinar Baru Algesindo.

[6] Sudjana, N. \& Rivai, A. (2005). Media Pengajaran. Bandung: C.V Sinar Baru Algesindo. 